\title{
NATURALISMO E TRANSFERÊNCIAS CULTURAIS: O CASO FRANÇA-BÉLGICA
}

\author{
MARINHO PEDROSA: Rubens Vinícius ${ }^{1}$ \\ FERREIRA CATHARINA, Pedro Paulo Garcia ${ }^{2}$
}

\begin{abstract}
RESUMO: Os escritores Camille Lemonnier e Joris-Karl Huysmans mantiveram trocas intelectuais e artísticas intensas ao discutirem questões relativas ao naturalismo, ao mesmo tempo que estabeleciam relações úteis e intermediavam contatos com editores e outros escritores entre a Bélgica e a França. Sendo Lemonnier belga e Huysmans francês, a circulação de ambos entre os dois campos literários é um exemplo do trânsito de agentes que favorece processos de transferência cultural entre campos literários distintos. As publicações desses escritores na França e na Bélgica nos anos 1870 nos conduzem a indagar sobre o modo como o naturalismo circulou e foi apropriado nos dois países. Pretendemos discutir tais questões a partir da noção de transferência cultural, oriunda de trabalhos de Michel Espagne e outros autores. Consideramos ainda o conceito de tribo, de Dominique Maingueneau, assim como as reflexões de Pierre Bourdieu e Pascale Casanova sobre o campo literário e a República Mundial das Letras.
\end{abstract}

PALAVRAS-CHAVE: Camille Lemonnier; Joris-Karl Huysmans; transferências culturais; naturalismo; campo literário.

\section{NATURALISME ET TRANSFERTS CULTURELS : LE CAS FRANCE-BELGIQUE}

RÉSUMÉ : Les écrivains Camille Lemonnier et Joris-Karl Huysmans ont entretenu d'intenses échanges intellectuels et artistiques tout en discutant de questions liées au naturalisme, tout en établissant des relations utiles et des contactes médiateurs avec des éditeurs et d'autres écrivains entre la Belgique et la France. Lemonnier étant belge et Huysmans français, leur circulation entre les deux champs littéraires est un exemple du transit d'agents qui favorise les processus de transferts culturels entre des champs

\footnotetext{
${ }^{1}$ Doutorando pelo Programa de Pós-Graduação em Letras Neolatinas - Universidade Federal do Rio de Janeiro, bolsista CAPES. E-mail: rubens.v.marinho.pedrosa@letras.ufrj.br ORCID: https://orcid.org/0000-0002-04285870

${ }^{2}$ Professor Associado Departamento de Letras Neolatinas e do Programa de Pós-Graduação em Letras Neolatinas da Universidade Federal do Rio de Janeiro. E-mail: pedrop@letras.ufrj.br ORCID: https://orcid.org/0000-00028104-1773
}

Jangada| ano 9, nr. 17, jan/jun, 2021 | ISSN 2317-4722 


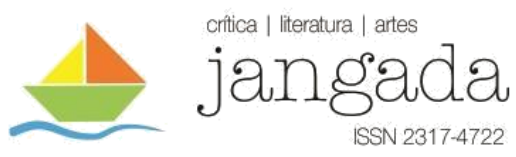

littéraires distincts. Les publications de ces écrivains en France et en Belgique dans les années 1870 nous amènent à étudier comment le naturalisme a circulé et a été approprié dans les deux pays. Nous nous proposons d'aborder ces questions à partir de la notion de transferts culturels, issue des travaux de Michel Espagne et d'autres auteurs. Nous nous penchons également sur le concept de tribu, de Dominique Maingueneau, ainsi que les réflexions de Pierre Bourdieu et de Pascale Casanova sur le champ littéraire et la République mondiale des lettres.

MOTS-CLÉS : Camille Lemonnier ; Joris-Karl Huysmans ; transferts culturels ; naturalisme ; champ littéraire.

As relações culturais entre a França e a Bélgica foram, ao longo da história, permeadas por tensões. Se, por um lado, durante o século XIX, o campo literário francês, em processo de autonomização, acumulava grande volume de capital simbólico e exercia certa dominação sobre o campo literário belga, especialmente através da violência simbólica (BOURDIEU, 1996, p. 315), por outro lado, a Bélgica buscava afirmar suas singularidades no âmbito das artes e da literatura frente ao país vizinho com quem tem em comum a língua francesa. No entanto, a circulação de editores, escritores e textos literários entre os dois países são uma constante desde antes das trocas efetuadas no âmbito da literatura naturalista, que examinaremos neste artigo. Uma estratégia muito comum a que escritores franceses recorriam na época do Segundo Império era a de publicar suas obras na Bélgica, visando fugir da censura que enfrentavam na França. Para citar apenas dois exemplos: a editora A. Lacroix, Verboeckhoven et Cie, de Albert Lacroix (1834-1903) e Hippolyte Louis Verboeckhoven (1827-1893), lançou diversas obras de escritores franceses exilados como Pierre-Joseph Proudhon (1809-1865), teórico e pensador socialista. A dupla de editores belgas ainda foi responsável pela primeira edição de Les Misérables (1862), de Victor Hugo (1802-1885), então exilado no país (DURAND in BERTRAND; BIRON; DENIS; GRUTMAN; 2006, p. 99).

No sentido contrário, a forte atração exercida por Paris sobre escritores constitui um fator de relativa preponderância no tocante às relações franco-belgas (CASANOVA, 1999, p. 50). Embora o campo literário belga tenha efetuado movimentos de afirmação de uma identidade literária própria, a capital francesa representava uma importante instância de legitimação para os escritores belgas francófonos. Alguns conseguiram se estabelecer na capital literária de então, como por exemplo o dramaturgo Maurice Maeterlinck (1862-1949), que pode ser considerado como aquele que de fato triunfou em Paris. O seu teatro simbolista foi muito bem-sucedido na capital francesa (GORCEIX, 1997, p. 685). A peça Pelléas et Mélisande 
(1892) foi encenada no Théâtre des Bouffes Parisiens, sob a direção de Aurélien Lugné-Poe (1869-1940), produtor e diretor teatral e um dos responsáveis pela renovação do teatro francês, assim como André Antoine (1858-1943). Este último levou aos palcos adaptações de romances naturalistas e propôs muitas inovações, como cenários e interpretações realistas. O poeta Émile Verhaeren (1885-1916), voltado principalmente para a estética naturalista, e o escritor e poeta simbolista Georges Rodenbach (1855-1898) também se encontram entre os autores belgas reconhecidos na capital literária de então (BIRON in BERTRAND; BIRON; DENIS; GRUTMAN, 2006, p. 142).

Outro escritor seria igualmente considerado uma figura emblemática da literatura belga francófona moderna: Camille Lemonnier (1844-1913). Romancista, contista, dramaturgo e crítico de arte, Lemonnier tem grande parte de sua obra literária vinculada à estética naturalista. Além disso, exerceu na Bélgica a função de editor de revistas literárias, como L'Actualité e L'Art universel. Em sua obra, buscou observar os costumes belgas, com destaque para o universo campesino flamengo, além de criar cenas que faziam referência a quadros de pintores da tradição flamenga dos séculos XVI e XVII, como Peter Paul Rubens (1577-1640), Jacob Jordeans (1593-1678) e David Teniers (1582-1649). Em sua primeira publicação, o volume contendo ensaios, críticas, crônicas e poemas em prosa Nos Flamands (1869), Lemonnier exorta os artistas contemporâneos a voltarem-se para a estética desses pintores, com seu colorido pulsante e suas representações de homens de sólida constituição física e mulheres de formas generosas. No volume Contes flamands e wallons (1873), apresenta narrativas que tematizam paisagens e costumes típicos tanto da região de Flandres quanto da Valônia. O título do livro de contos evidencia duas regiões cujas culturas seriam partes constitutivas da cultura belga: a francófona, concentrada sobretudo na região da Valônia, e a flamenga, que se encontra na região de Flandres. Da junção das duas metades origina-se a chamada "alma belga", como sintetizou Lemonnier no ensaio La Vie belge, de 1902 (LEMONNIER in GORCEIX, 1997, p. 78).

Assim como alguns outros escritores seus compatriotas, Lemonnier se aventurou em Paris, lá publicando livros e textos em jornais e revistas. Em carta enviada por Joris-Karl Huysmans (1848-1907), o escritor francês questiona o fato de Lemonnier não residir em Paris: "E me perguntam por que diabos, com o talento que você tem, você não é um habitante de Paris” (HUYSMANS, 1957, p. 1). ${ }^{3}$ Tal indagação corresponde não apenas ao reconhecimento

3 “[...] et l'on me demande pourquoi diable avec le talent que vous avez, vous n'êtes pas habitant de Paris [...]". As traduções presentes nesse artigo, salvo quando indicado, são de responsabilidade dos autores.

Jangada| ano 9, nr. 17, jan/jun, 2021 | ISSN 2317-4722

293 | Pá g i n a 


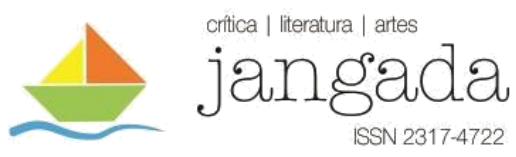

de seu talento por parte de seus pares, mas também à força centrípeta exercida por Paris e ao modo como a cidade funcionaria como uma instância legitimadora para os escritores francófonos (BOURDIEU, 1996, p. 175; CASANOVA, 1999, p. 41-55).

Huysmans mantinha uma intensa relação de trocas profissionais com Lemonnier, tanto no nível estético quanto em ligações úteis no campo literário, servindo de mediador entre editores e outros escritores, conforme demonstra a correspondência entre eles. O escritor francês, cuja obra também se filiava ao naturalismo, frequentava o meio literário e artístico belga, colaborando com diversas revistas do país. Além disso, no âmbito estético, sentia-se próximo dos Países Baixos de um modo geral e da Bélgica em particular. Seu primeiro livro, o volume de poemas em prosa Le Drageoir aux épices (1874), é em grande parte fruto do resgate de seu passado familiar (ele descendia de pintores holandeses), de um aprendizado estético iniciado com a observação dos quadros de mestres flamengos e holandeses no Museu do Louvre e em temporadas passadas na Holanda e na Bélgica (CATHARINA, 2005, p. 104). Assim, podemos, a princípio, enxergar a obra literária de Lemonnier como composta de um elemento cultural híbrido, flamengo e francófono, e Huysmans como uma espécie de elo entre os campos literários francês e belga. Indo além, podemos tomar a relação entre Huysmans e Lemonnier como sintomática das trocas e intercâmbios culturais existentes entre a França e a Bélgica, compreendidos aqui sob a ótica das transferências culturais.

Após breves considerações sobre a noção de transferência cultural, enfocando especialmente as ocorridas entre a França e a Bélgica francófona, pretendemos discutir algumas publicações de Lemonnier e Huysmans em jornais e revistas na França e na Bélgica na década de 1870, atendo-nos principalmente aos contos de Lemonnier veiculados no Le Figaro e ao estudo efetuado por Huysmans sobre o romance L 'Assommoir, de Émile Zola (1840-1902). Foi durante esse período que ocorreu parte importante das publicações dos escritores em questão, sobretudo no que diz respeito a importantes revistas literárias belgas. Através desse recorte, tencionamos observar a circulação de autores e textos entre os dois países, o modo como se dão as interações entre escritores e o tipo de sociabilidade que se estabelece a partir delas. Pretendemos, com isso, por um lado elucidar a relação do escritor belga com a capital literária de então, com o auxílio de reflexões de Pierre Bourdieu sobre o campo literário e a centralidade de Paris na segunda metade do século XIX, vista por Pascale Casanova. Por outro lado, destacaremos a publicação da série de artigos de Huysmans nas revistas L'Actualité e L'Artiste, analisando igualmente o envolvimento dos periódicos belgas na luta midiática em torno do naturalismo. Tais órgãos se afirmam como um ponto de confluência para os escritores Jangada | ano 9, nr. 17, jan/jun, 2021 | ISSN 2317-4722 


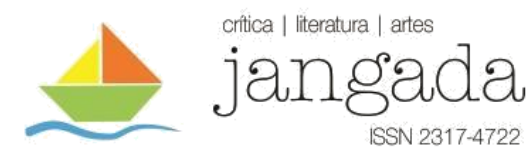

naturalistas franceses e belgas, o que os caracterizaria como uma tribo, no entender de Dominique Maingueneau (1993).

$\mathrm{Na}$ última parte deste artigo, efetuaremos uma discussão em torno do conceito de transferência cultural a partir da relação do naturalismo no eixo Bélgica-França. Consideraremos o intercâmbio nos níveis estéticos e de relações úteis no campo literário realizado entre Lemonnier e Huysmans e o posicionamento das revistas literárias belgas no que diz respeito à estética naturalista, visando compreender o desenvolvimento desta última no eixo França-Bélgica.

\section{TRANSFERENCIAS CULTURAIS E LITERATURA MUNDIAL}

A noção de transferência cultural é oriunda dos trabalhos de Michel Espagne e Michel Werner que, debruçando-se sobre as trocas efetuadas entre a França e a Alemanha, buscaram elucidar o modo como se deram a importação e a ressignificação de elementos estrangeiros que se tornaram partes constitutivas da cultura francesa, como é o caso da filosofia alemã no século XIX. Espagne entende por transferência cultural uma orientação metodológica "com vistas a pôr em evidência as imbricações e as mestiçagens entre os espaços nacionais ou, de modo mais geral, entre os espaços culturais, numa tentativa de compreender por quais mecanismos as formas identitárias podem se alimentar de importações” (ESPAGNE, 2012, p. 21). É possível compreender, através desses processos denominados transferências, que não se poderia falar em termos de forma ou produto cultural "original" ou "legitimamente nacional", pois eles já seriam resultantes de importações anteriormente ocorridas.

Segundo o próprio Espagne, o estudo das transferências culturais leva a reconhecer que é possível "se apropriar de um objeto cultural e se emancipar do modelo que ele constitui, ou seja, uma transposição, por mais distante que ela seja, tem tanta legitimidade quanto a original" (ESPAGNE, 2013, p. 2). ${ }^{4}$ Sendo assim, ao tratar de um caso de transferência cultural, como aquele que ocorre entre a França e a Alemanha, e o que se propõe aqui entre a França e a Bélgica, não se aplicaria a ideia de simples apropriação de um elemento cultural estrangeiro ou de "influência". Joseph Jurt avalia esta última como uma noção problemática justamente porque implicaria, no caso da disseminação de uma literatura nacional em outros espaços, uma ideia

\footnotetext{
${ }^{4}$ La recherche sur les transferts culturels devait admettre qu'on peut s'approprier un objet culturel et s'émanciper du modèle qu'il constitue, c'est-à-dire qu'une transposition, aussi éloignée soit-elle, a autant de légitimité que l'original.
}

Jangada | ano 9, nr. 17, jan/jun, 2021 | ISSN 2317-4722 


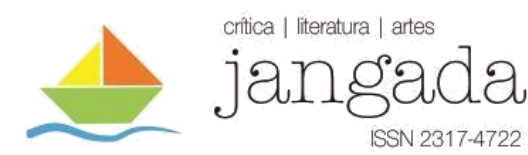

de "superioridade" da cultura emissora sobre a receptora (JURT in LOMBEZ; KULESA, 2007, p. 97). A apropriação, por outro lado, seria apenas a primeira etapa do processo de transferência após a importação, seguindo-se a aclimatação e a ressignificação.

Os estudos das transferências culturais, possuindo o intuito de colocar em questão categorias pautadas pela noção do nacional, procuram compreender o "processo de translação de um produto cultural entre seu contexto de surgimento e um novo contexto de recepção" (ESPAGNE, 2012, p. 23). Desse modo, diversas instâncias de mediação são consideradas, como viajantes, tradutores, livreiros, editores, colecionadores, bibliófilos, entre outros. Eles seriam agentes sociais que cruzam determinada fronteira levando consigo produtos culturais para serem apropriados e ressignificados. Esses mediadores podem ser definidos como uma força motriz envolvida no processo de transferência cultural. Na definição de Ahmed Silem, o mediador seria um "ator que contribui para a mediação cultural, ou seja, a difusão e a apropriação de produtos culturais" entre diferentes países e áreas culturais (SILEM in COOPER-RICHET; MOLIER; SILEM, 2005, p. 301). Conforme avalia Diana Cooper-Richet, essa figura pode assumir diversas identidades, levando-se em consideração a sua natureza variada (COOPER-RICHET, 2013, p. 131). Um mediador pode ser um indivíduo, como um tradutor, um editor ou um padre evangelizador, mas também um grupo de pessoas, como uma associação de difusão cultural, uma congregação religiosa, uma editora.

As transferências culturais são compreendidas como interações complexas entre diversos polos linguísticos ou espaços culturais. (ESPAGNE, 2013, p. 3). Elas não se dão apenas entre idiomas ou territórios políticos diferentes, sendo possível que ocorram entre espaços culturais coexistentes dentro de um mesmo país e entre países que têm em comum o mesmo idioma. Espagne observa que "a revisão da história literária sob o ângulo das transferências culturais permite evidenciar a circulação de modelos que são vistos como fundadores das literaturas nacionais" (ESPAGNE, 2013, p. 5). ${ }^{5}$ Mesmo obras consideradas fundadoras para um Estado-Nação, como é o caso de La Chanson de Roland (c. 1130) para a França, por exemplo, corresponderiam a um texto cuja forma e temática - no caso, a do poema épico narrando feitos heroicos - encontram outros exemplos análogos em diversos países, até mesmo naqueles mais distantes, como A História de Kieu no Vietnã (ESPAGNE, 2013, p. 5). Assim, estabelecendo um paralelo com a literatura naturalista na França e na Bélgica, do nosso ponto de vista, não seria adequado pensar em termos de "originalidade" francesa. Ao adotarmos

\footnotetext{
${ }^{5}$ La révision de l'histoire littéraire sous l'angle des transferts culturels permet de mettre en évidence la circulation des modèles censés fonder des littératures nationales.
}

Jangada | ano 9, nr. 17, jan/jun, 2021 | ISSN 2317-4722 


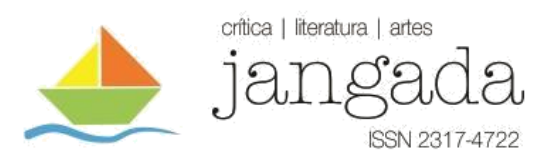

a noção de transferência cultural, pretendemos igualmente colocar em questão a noção de "influência" que permeia de forma recorrente os estudos literários.

A originalidade se associa frequentemente à chamada "literatura nacional", como forma de afirmar a superioridade do conjunto literário de determinado país sobre outros. Segundo Joseph Jurt, o conceito de literatura nacional já vinha sendo relativizado no início do século XIX, especialmente por Johann Wolfgang von Goethe (1749-1832), que propunha o conceito de Weltliteratur, ou literatura mundial. A partir de então, intentava-se ultrapassar a ideia de uma literatura estritamente nacional, como havia sido formulada pelos românticos (JURT in LOMBEZ, KULESA, 2007, p. 93). Pascale Casanova, por sua vez, concebe as chamadas literaturas nacionais e suas imbricações através da constituição de uma República Mundial das Letras, segundo a qual a literatura poderia ser definida como um campo internacional unificado ou em vias de unificação (CASANOVA, 1999, p. 179). A manutenção desse sistema depende da existência de agentes que atuem como intermediários transnacionais, como homens de letras, críticos e escritores. Eles são os encarregados de intermediar a transferência de uma obra pela qual eles próprios advogam, por valorizarem seu valor literário (CASANOVA, 1999, p. 39).

Goethe propunha, como modo de favorizar a constituição de uma literatura mundial, a tradução, contatos mútuos entre escritores de diferentes nações e a utilização de revistas e jornais de orientação internacional como plataforma (JURT in LOMBEZ; KULESA, 2007, p. 95). Ele destacava, desse modo, o papel mediador que os contatos entre os escritores e as revistas literárias que publicassem seus textos poderiam ter, fazendo com que as estéticas literárias ou as chamadas "grandes revoluções específicas" circulassem internacionalmente e fossem assimiladas em outros espaços nacionais (CASANOVA, 1999, p. 180).

\section{AS PUBLICAÇÕES DE LEMONNIER NA FRANÇA: RELAÇÕES ÚTEIS E FORÇA CENTRÍPETA}

Camille Lemonnier teve uma prolífica produção literária, reconhecida por seus romances naturalistas como Un Mâle (1882), Le Mort (1882) Happe-chair (1886), L'Homme en amour (1897) e Adam et Ève (1899). Dedicou-se com igual afinco a outros gêneros literários, como a crítica de arte, o conto e o poema em prosa, publicados tanto em jornais e revistas quanto em livro, além de ter sido fundador e editor de revistas literárias, como L'Actualité e L'Art universel. Lemonnier praticou igualmente a dramaturgia, adaptando para os palcos os romances Jangada| ano 9, nr. 17, jan/jun, 2021 | ISSN 2317-4722 


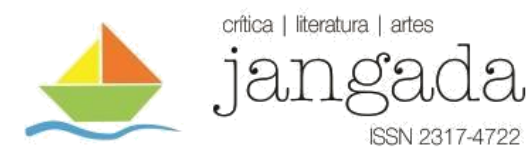

Un Mâle (Un Mâle; pièce en quatre actes,1891) e Le Mort (Le Mort; minodrame en trois actes, 1894). O primeiro, em coautoria com Anatole Bahier (1858-1918), ator e dramaturgo francês, e Jean Dubois; o segundo, com Paul Martinetti (?-1924), com música do compositor belga Léon Du Bois (1859-1935). Lemonnier escreveu ainda a tragédia lírica Edénie (1910), também com música de Du Bois. Além disso, um compilado de suas peças foi publicado em 1899 por Paul Ollendorff (1859-1935), editor e livreiro parisiense. O volume contém as peças La Mort; farce tragique en 3 actes, Les Mains; tragédie en 5 actes e Les Yeux qui ont vu; un acte. ${ }^{6}$

O romance que faria com que Lemonnier tivesse sua notoriedade expandida no campo literário belga foi Un Mâle, que permanece até os dias atuais como uma de suas obras mais conhecidas. Narrando os idílios entre um caçador e a enteada de um fazendeiro, traz uma ambientação campesina que poderia ter saído de um quadro de Pieter Brueghel (c.1525-1569), ao efetuar a descrição pictural (LOUVEL, 2002, p. 15) de cenas caras à tradição pictórica flamenga como as quermesses, pintadas por artistas como Rubens. ${ }^{7}$ Un Mâle foi publicado pelo editor belga Henry Kistemaeckers (1851-1934), considerado o editor dos naturalistas na Bélgica. Antes disso, o escritor havia publicado outras obras: em 1871, o livro-reportagem Sedan, no qual descreve os horrores da sangrenta batalha ocorrida na cidade francesa de Sedan, em 1870, durante a Guerra franco-prussiana. Em 1881, Sedan seria reformulado em forma de romance, publicado sob o título de Les Charniers. Nesse meio tempo, em 1879, Lemonnier lançou o romance Un Coin de village, pelas mãos do editor francês Alphonse Lemerre (18381912), reputado pela publicação de volumes de poetas parnasianos (MOLLIER, 2004, p. 252). No entanto, por volta de 1877, Lemonnier havia oferecido o romance ao editor parisiense Édouard Dentu (1830-1884), que havia publicado Le Drageoir aux épices, de Huysmans, alguns anos antes. $\mathrm{O}$ escritor francês chega a alertar Lemonnier sobre esse editor, em carta datada de agosto de 1877: "Sobre o seu romance que está com Dentu - acho que você deve pressionar aquele balofo, pois ele tem a reputação de, se não o apressam, deixar os manuscritos embolorar nas gavetas." (HUYSMANS, 1957, p. 42). ${ }^{8}$ A passagem em questão é um bom indício de como podiam se dar as relações dos escritores com editores, jornais e revistas literárias e outros escritores, entre a França e a Bélgica.

\footnotetext{
${ }^{6}$ Conhecemos a existência deste volume, devido à ficha catalográfica na Bibliothèque Nationale de France (https://catalogue.bnf.fr/ark:/12148/cb41888533x).

${ }^{7}$ Tratamos das descrições picturais e transposições de arte presentes no romance Un Mâle no artigo "Quadros de quermesse em Un mâle, de Camille Lemonnier: um topos naturalista" (PEDROSA; CATHARINA, 2019).

8 "Et votre roman avec Dentu - je crois que vous ferez bien de pousser ce pain de suif, car il a la réputation, s'il n'est pas talonné, de laisser chancir les manuscrits dans les tiroirs."
}

Jangada | ano 9, nr. 17, jan/jun, 2021 | ISSN 2317-4722 


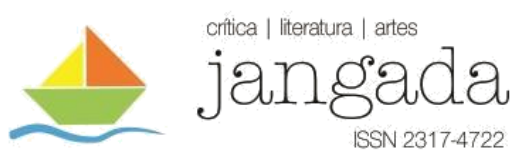

Observamos que a publicação de algumas obras de Lemonnier na década de 1870 , antes que ele se firmasse no campo literário belga como romancista, ocorreram em Paris. Além de Un Coin de village, o volume Contes flamands et wallons foi publicado pela Librairie de la société des gens de lettres, na capital francesa. Há também um Salon de Paris que Lemonnier lançou em 1870 pela editora Veuve A. Morel et compagnie. Vale notar que o escritor, assim como muitos de seus homólogos franceses como Zola e Huysmans, começou sua carreira no âmbito da crítica de arte, no qual os Salões oficiais de pintura eram bastante visados. $\mathrm{O}$ fato de Lemonnier publicar na França no momento inicial de sua carreira poderia ser compreendido como um movimento do escritor em direção a um reconhecimento em Paris, tendo em vista a atração exercida pela capital literária de então. As suas publicações em jornais e revistas na França podem corroborar essa hipótese. Pascale Casanova pondera sobre a centralidade de Paris, relacionando esse status da capital francesa como resultado, por um lado, de um liberalismo político e, por outro, de uma incessante série de representações do imaginário (CASANOVA, 1999, p. 50). A chamada "mitologia parisiense", que compreende notadamente a agitada vida cultural, os círculos literários e a boêmia artística, colaboraria para atrair uma grande quantidade de artistas estrangeiros. Esse mesmo imaginário sobre Paris como capital cultural a colocava como uma importante força legitimadora, além de uma passagem quase obrigatória para escritores que quisessem integrar a chamada "literatura mundial" (CASANOVA, 1999, p. 39).

Lemonnier colaborou com periódicos na França, em especial com o jornal parisiense Le Figaro. Em seu suplemento literário dominical, na edição de 5 de novembro de 1876, foi publicado o conto "Morts d'automne". A curta história dialogada tematiza a ocasião do enterro de um pintor, sendo dividida em três partes: "Folie", "Phithsie" e "Indigestion". Chama a atenção, nessa publicação, a nota que a antecede, que indica que o texto havia sido encontrado em uma série de manuscritos empilhados, enviados há tempos à redação do jornal:

Concebemos que, em um jornal como Le Figaro, que logo terá um quarto de século de existência, haja um certo canto onde dorme, em silêncio e em tranquilidade, um grande número de manuscritos de todas as idades, de todas os tamanhos e de todas as cores. Há algum tempo, um pouco de sol e de rumor adentra esse local escondido. Certos dias, executamos escavações para incrementar nosso suplemento literário. Foi assim que descobrimos um manuscrito do Sr. Camille Lemonnier, um contista muito conhecido. Esse 


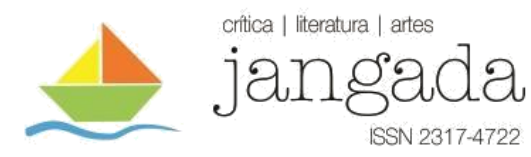

manuscrito se intitula "Les Morts d'automne". Ele permanece totalmente atual. Nós o publicamos agora, persuadidos de que seu autor ficará bastante surpreso de encontrar aqui um filho talvez já esquecido (LE FIGARO, 1876, p. 185$){ }^{9}$

Destacamos na nota o fato de Lemonnier ser referido como "um contista bastante conhecido". Isso mostra o investimento genérico por parte do escritor ao longo da década de 1870 em formas curtas, compreendendo contos e poemas em prosa. Além disso, os editores do jornal afirmam ter encontrado o conto em uma série de manuscritos enviados à redação, mas que podem não ter sido considerados para publicação. Se, na época em que enviou tais manuscritos o escritor belga não era muito conhecido, quando o conto foi finalmente publicado, ele já havia adquirido certa reputação como contista no meio editorial francês.

Um fato que, ao menos à primeira vista, não tem muita relação com essa nota nem com o conto em si, é a publicação por Lemonnier, em 1870, do volume de poemas em prosa Croquis d'automne, pelo editor C. Muquardt, em Bruxelas. O livro compõe-se de uma série de quadros (ou croquis, como o título indica), nos quais se destacam o paisagismo e sobretudo as cores alusivas ao outono. As peças que compõem Croquis d'automne foram escritas com o intuito de serem enviadas para um concurso do jornal parisiense Le Figaro. No entanto, o concurso acabou não ocorrendo (BROGNIEZ in BERTRAND; BIRON; DENIS; GRUTMAN, 2006, p. 118). Podemos supor, pela coincidência dos títulos e pelo fato de o manuscrito ter sido encontrado entre outros que haviam sido enviados ao jornal, que os poemas em prosa de Croquis d'automne e a narrativa dialogada "Les Morts d'automne" originalmente fizessem parte de um mesmo conjunto de textos. Entretanto, no que diz respeito à forma e à temática, são textos completamente diferentes. Porém, podemos assinalar, tanto em relação ao conto quanto aos poemas em prosa, a força centrípeta que, invariavelmente, atraía o escritor a Paris.

Lemonnier teve outros textos publicados no Figaro, entre eles o conto "Le Colis 2775", na edição de 02 de abril de 1876, "La Vie et ses jouets", em 8 de setembro de 1878 e

\footnotetext{
${ }^{9}$ On conçoit que dans un journal comme le Figaro, qui aura tantôt un quart de siècle d'existence, il y ait un certain coin où dort, dans le silence et la tranquillité, un grand nombre de manuscrits de tout âge, de toute dimension et de toute couleur. Depuis quelque temps, un peu de jour et de bruit pénètre dans cet endroit reculé. A certains jours, on y exécute des fouilles au profit de notre Supplément littéraire. Voilà comment nous avons découvert un manuscrit de M. Camille Lemonnier, un conteur bien connu. Ce manuscrit était intitulé : les Morts d'automne. Il tombait en pleine actualité. Nous le publions, persuadés que son auteur sera bien étonné de retrouver ici un enfant peut-être oublié.
}

Jangada | ano 9, nr. 17, jan/jun, 2021 | ISSN 2317-4722 


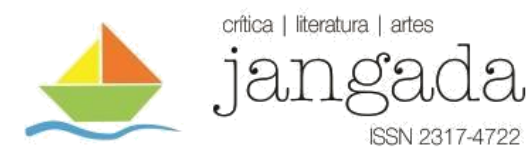

“La Petite sœur", em 22 de setembro de 1878. Na nota que anuncia este último, o escritor é apresentado do seguinte modo:

Publicamos, há algum tempo, uma delicada peça literária de um escritor belga que possui um talento cheio de charme e que merece ser mais bem conhecido na França. Trata-se do "La Vie et ses jouets", do Sr. Camille Lemonnier.

Eis aqui uma outra narrativa muito emocionante do mesmo autor, que recomendamos insistentemente aos nossos leitores (LE FIGARO, 1878, p. 147). ${ }^{10}$

O responsável pela publicação do conto trata Lemonnier com termos elogiosos, realçando o talento do escritor, avaliando que ele deveria ser mais conhecido na França. A nota aponta para um determinado renome que o escritor buscava em Paris que, entretanto, não teria chegado a obter.

O modo como Bourdieu elucida questões acerca do reconhecimento de um escritor no campo literário indica que ele ocorre em uma via de mão dupla: por um lado, opera uma lógica antieconômica, na qual o lucro obtido é sobretudo simbólico, advindo do reconhecimento de pares e de instâncias legitimadoras, como a crítica e as academias. Por outro lado, o campo funciona dentro de uma lógica mercantilista, no qual os proventos financeiros, as tiragens e as demandas do público são priorizados (BOURDIEU, 1996, p. 163). Essas duas lógicas dificilmente coincidem e o escritor geralmente se vê obrigado a optar entre o ganho simbólico e o material. Para o sociólogo, a literatura naturalista pode, no entanto, ser considerada como um caso especial, no qual esses dois polos poderiam se encontrar, pois, apesar de grande parte de os romances pertencentes a essa estética terem obtido sucesso de público, eles correspondiam a um projeto literário cujas exigências específicas de forma e conteúdo eram observadas (BOURDIEU, 1996, p. 134).

Haveria, desse modo, uma diferença entre reconhecimento entre pares e sucesso de público, os dois raramente coexistindo. Com relação a Lemonnier, é possível dizer que ele chegou a ter um considerável reconhecimento junto ao meio literário e editorial francês,

\footnotetext{
${ }^{10}$ Nous avons donné, il y a quelque temps, un fin morceau littéraire d'un écrivain belge qui possède un talent plein de charme, et qui mérite d'être mieux connu en France. C'était La Vie et les Jouets, de M. Camille Lemonnier. Voici un autre récit très touchant du même auteur et que nous recommandons tout particulièrement à nos lecteurs. 
compreendendo editores, responsáveis pela redação de jornais e revistas e outros escritores, mas o mesmo não ocorre junto ao público-leitor.

Lemonnier havia ainda colaborado, anteriormente, com a revista parisiense Musée des deux mondes, na qual publicou uma série de poemas intitulada Études d'après nature, nas edições de $1^{\circ}$ e 15 de julho, 15 de agosto, 15 de setembro, $1^{\circ}$ e 15 de outubro de 1876 (VANWELKENHUYZEN, 2015, p. 30-31). A revista, dirigida pelo crítico de arte Eugène Montrossier (1839-18?), propunha, além de textos, litografias e águas-fortes. Tratava-se, podemos inferir, de uma publicação de público restrito, o que nos conduz ainda a reafirmar a ideia de que Lemonnier teria apenas certo reconhecimento de seus pares em Paris. Colaboraram igualmente com a Musée des deux mondes nomes como o escritor naturalista Paul Alexis (18471901), Catulle Mendès (1841-1909), fundador e editor de La République des Lettres, e Huysmans, que aí publicou, em $1^{\circ}$ de junho, "Croquis et eaux fortes" e "Maître Karel Brand", oriundos de Le Drageoir aux épices (VANWELKENHUYZEN, 2015, p. 30). A publicação de Lemonnier nessa revista, ao lado desses escritores, indicaria uma espécie de estreitamento de laços entre escritores franceses e belgas na década de 1870, que será efetivo nas publicações de Huysmans e outros naturalistas franceses em revistas literárias belgas.

\section{HUYSMANS E AS REVISTAS LITERÁRIAS BELGAS: POSICIONAMENTOS, LUTAS E RELAÇÃO DE TRIBO}

Huysmans possuía uma grande proximidade com o meio literário belga. Tal familiaridade causou até mesmo alguns mal-entendidos, como o que ocorreu quando precisou esclarecer a um de seus correspondentes belgas, o poeta Georges Ramaekers (1875-1955), que não era um compatriota, mas um parisiense de ascendência holandesa (VANWELKENHUYZEN, 2015, p. 47-48). Tal ambiguidade pode ter sido ocasionada por seu nom de plume, criado para marcar sua ascendência holandesa, na ocasião da publicação de Le Drageoir aux épices (seu nome de batismo era Charles-Marie-Georges), ou pelo fato de Huysmans frequentar durante um longo período o meio literário belga, publicando alguns de seus romances com editores belgas e também artigos, contos e poemas em prosa em revistas literárias no país. Seu primeiro romance naturalista, Marthe; histoire de une fille (1976) surgiu pela primeira vez na Bélgica, pelas mãos de Jean Gay (1837-188?), editor e livreiro francês residente em Bruxelas. Seguiram-se outros romances, lançados sempre por editores parisienses: Les Sœurs Vatard saiu, em 1878, pelas mãos de Georges Charpentier (1846-1905). Responsável por editar a obra de Émile Zola, Jangada | ano 9, nr. 17, jan/jun, 2021 | ISSN 2317-4722 


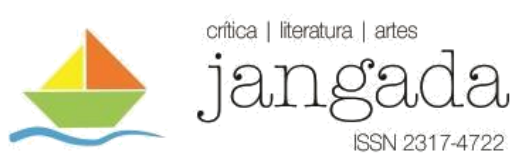

Charpentier era reputado pela publicação dos escritores naturalistas franceses, tendo mesmo um grande peso simbólico nos volumes que levavam seu nome (MOLLIER, 2011, p. 33). De Huysmans, Charpentier ainda publicou En ménage, em 1881, e À Rebours, em 1884. Outras obras do escritor como En rade (1887), Là-bas (1891) e En Route (1895) saíram pela editora Tresse et Stock.

Entre as revistas literárias belgas para as quais Huysmans enviou colaborações está a L'Actualité. Ela foi fundada em 1876 por Camille Lemonnier e tinha como proposta ser voltada principalmente para a crítica de arte. Além de editar a revista, Lemonnier assinava boa parte das rubricas, utilizando diversos pseudônimos (VANWELKENHUYZEN, 2015, p. 31-32). Nas edições 4 e 5 do periódico, de 10 e 17 de setembro de 1876, respectivamente, Huysmans publicou em duas partes o conto "Adrien Brauwer", que havia integrado seu primeiro livro de poemas em prosa, Le Drageoir aux épices, publicado dois anos antes. Chama a atenção o fato de a versão veiculada em L'Actualité ter sofrido sensíveis modificações em relação àquela de Le Drageoir aux épices, considerando que a republicação em revista deu-se dois anos após a publicação em livro. Normalmente, quando se trata de publicações de textos literários em suportes efêmeros, elas são normalmente tidas como versões preliminares que, após passar por eventuais modificações, têm no livro - suporte mais estável em relação à revista literária - sua versão definitiva (DISEGNI, 2008, p. 73). É possível cogitar que Huysmans tenha visto na republicação de "Adrien Brauwer" a chance de ainda introduzir modificações que não teriam sido possíveis após a publicação em livro, efetuando, assim, em sua obra, um movimento às avessas dos modos usuais de publicação.

Foi igualmente veiculada em L'Actualité uma série de artigos que Huysmans escreveu em defesa de Émile Zola e de seu romance L'Assommoir (1876-77), objeto de grande polêmica na imprensa e nos círculos literários parisienses. Os artigos saíram em quatro partes, nas edições de n. 30, 31, 32 e 33, nos dias 11,18 e 25 de março e $1^{\circ}$ de abril de 1877 , respectivamente. $O$ controverso romance naturalista de natureza trágica narra a trajetória da lavadeira Gervaise que, após período de luta e de ascensão social, acaba sucumbindo ao vício do álcool e à miséria. No romance de escândalo, Zola pinta de forma crua a vida da classe operária e a luta pela sobrevivência, em ambiente por vezes muito hostil. Antes que a série de artigos começasse a aparecer na revista dirigida por Lemonnier, os textos foram assunto recorrente na correspondência entre os dois escritores. Em carta datada de 15 de fevereiro de 1877, Huysmans discorre sobre o artigo que iria escrever: 


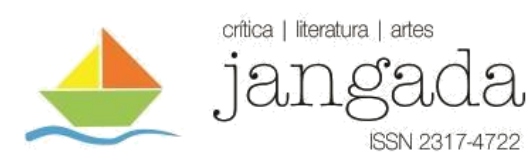

Você me pergunta se posso lhe dar um artigo sobre o livro de Zola - nada me alegraria mais, especialmente porque, além da admiração que tenho pelo artista, prezo demais o homem, que é bom e distinto. Se quiser, faço para você um Zola de pantufas, o Zola desconhecido, o bebedor de sangue que vive tranquilamente no seu canto com sua esposa, recebendo apenas 5 ou 6 fiéis discípulos - entre os quais tenho a honra de estar - quinta-feira à noite. Isso poderia ser interessante (ainda mais que nunca foi feito), e como início de um artigo sobre L'Assommoir, não seria nada mal, creio. (HUYSMANS, 1957, p. $15)^{11}$

Huysmans faz referência ao pedido que Lemonnier havia feito, para que escrevesse um artigo sobre o romance de Zola a ser publicado em L'Actualité. Isso mostra que Lemonnier estava inteirado do que havia ocorrido em Paris após a publicação do romance de Zola, com a polêmica por ele suscitada. A abordagem que Huysmans pretende então dar ao artigo mostrando Zola como um homem que vive uma vida burguesa ao lado de sua esposa e um escritor dedicado, que recebe alguns poucos pares em reuniões semanais, é de fato o modo como o autor acaba desenvolvendo a primeira parte de seu artigo.

O trecho da carta mostra Huysmans negociando o desenvolvimento do artigo, segundo o interesse do editor da revista e seus intentos, mas percebemos igualmente o modo como circulavam as informações, as novidades e sobretudo as polêmicas entre os campos literários belga e francês. A série de artigos críticos constituiria parte de um combate comum entre os campos literários francês e belga na defesa da estética naturalista, acusada de ser uma literatura imoral, frequentemente alvo de censura e de críticas acerbas por parte dos veículos midiáticos da época e dos pares. Desse modo, Huysmans, ao redigir os artigos, e Lemonnier, ao publicálos em sua revista, estariam se engajando pelo naturalismo. A polêmica que ocorria na imprensa era igualmente vista como um meio para que a literatura naturalista adquirisse visibilidade, conforme Huysmans manifesta em outro trecho da mesma carta: "Estamos em plena luta, os jornais atacam, mas constatam nossa existência, e isso já é muito" (HUYSMANS, 1957, p.

\footnotetext{
${ }^{11}$ Vous me demandez si je puis vous donner un article sur le livre de Zola - je ne demande pas mieux, d'autant qu'en dehors de l'admiration que j'ai pour l'artiste, j'aime beaucoup l'homme qui est bon et exquis. Si vous le voulez, je vous fais un Zola en pantoufles, le Zola inconnu, le buveur de sang qui vit tranquillement dans un coin, avec sa femme ne recevant, le jeudi soir, que 5 ou 6 personnes ses fidèles - parmi lesquels j'ai l'honneur d'être cela pourrait être intéressant (d'autant que ça n'a jamais été fait) et comme début d'un article sur L'Assommoir, cela ne serait pas mal je crois.
}

Jangada | ano 9, nr. 17, jan/jun, 2021 | ISSN 2317-4722 
15). ${ }^{12}$ Alain Pagès avalia da seguinte maneira as polêmicas literárias e o modo como elas se convertem em espetáculos midiáticos:

Considerem, por exemplo, essas estranhas disputas midiáticas no decorrer das quais a reputação interpela os escritores. [...] Colocados sob o olhar do público, eles só pensam nesses distantes juízes da celebridade que são os espectadores. Pouco importa a verdade em seu combate. O importante é o espetáculo que oferecem, a imagem que desejam imprimir nas consciências e que deve lhes trazer, assim esperam, a palma da notoriedade (PAGÈS, 1989, p. 8$){ }^{13}$

Pagès sintetiza como se dá o jogo midiático no qual, mais do que a verdade da luta, parece interessar a impressão que vai ser deixada junto ao público e o modo como isso vai afetar a notoriedade de determinado escritor ou grupo de escritores. Sem diminuir o valor do combate pela imposição de um ponto de vista estético inovador, configurando um desafio às convenções (BOURDIEU, 1996, p. 149), o espetáculo midiático e a visibilidade advinda eram usados pelos escritores em favor de seus projetos literários. No que concerne à literatura naturalista, sua recepção nos meios literário, editorial e midiático foi motivo de diversas celeumas. Um artigo escrito pelo jornalista, dramaturgo e escritor Louis Ulbach (1822-1889), publicado no Le Figaro de 23 de janeiro de 1868, denunciava a invasão daquilo que chamava de "literatura pútrida" (PAGÈS, 1989, p. 15). O artigo criticava, entre outras obras, Thérèse Raquin (1867), primeiro romance de Zola marcadamente naturalista. A polêmica se estenderia pelos anos seguintes, chegando a um ápice com L'Assommoir. A publicação deste romance também configurou um marco simbólico para o naturalismo, além de ter possibilitado a Zola ganhos simbólicos e financeiros (o escritor chega mesmo a comprar, com os lucros obtidos pela venda do romance, sua propriedade em Médan, imortalizada em 1880 com o lançamento de Les Soirées de Médan). Conforme situa Casanova, o período de grande sucesso do romance naturalista na França teria sido entre o ano de 1877, no qual a versão em livro de L'Assommoir foi publicada, e o ano de 1880, ocasião em que saiu Le Roman expérimental, série de artigos

\footnotetext{
${ }^{12}$ Nous sommes en pleine lutte, les journaux attaquent mais constatent notre existence, c'est beaucoup.

${ }^{13}$ Considérez, par exemple, ces étranges joutes médiatiques au cours desquelles la renommée apostrophe les écrivains. [...] Placés sous le regard du public, ils n'ont de pensée que pour ces juges lointains de la célébrité que sont les spectateurs. Peu importe la vérité de leur combat. L'important est le spectacle qu'ils donnent, l'image qu'ils souhaitent laisser imprimée dans les esprits, et qui doit leurs apporter, espèrent-ils, la palme de la notoriété.
} 


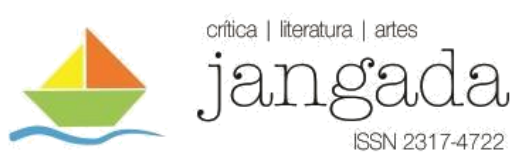

que Zola havia publicado em periódicos e que visava sistematizar o seu projeto literário. No entanto, em países como a Alemanha, por exemplo, obedecendo à lógica temporal própria de outro campo literário, o naturalismo teria tido grande desenvolvimento entre os anos de 1883 e 1889 (CASANOVA, 1999, p. 146).

Outras vozes de grande alcance se juntavam aos detratores da literatura naturalista, entre as quais se encontrava o eminente crítico literário Ferdinand Brunetière (1849-1906). Predominava, em grande parte das críticas dirigidas ao romance naturalista, a acusação de que ele explorava temas baixos, grotescos e banais, sem trazer nenhum fundo moralizante. Victor Hugo foi uma das vozes contrárias a Zola e ao movimento naturalista, repreendendo o escritor justamente por não haver abordado a miséria com um tom moralizante, como ele próprio havia feito em Les Misérables, mas por haver feito das mazelas das classes populares um espetáculo, tratando-as com indiferença (CATHARINA, 2001, p. 244). Huysmans, por outro lado, valoriza em sua série de artigos o tipo de expressão artística buscada pelo naturalismo, afirmando-a como legítima frente aos que lhe eram críticos:

Mas antes de estabelecer teorias que me são completamente pessoais que, adianto-me em dizer, não são de responsabilidade do jornal que as publica, talvez não fosse inútil definir essas palavras interpretadas de maneiras tão diversas: o realismo e o naturalismo. De acordo com alguns e, é preciso admitir, de acordo com a opinião mais difundida, o realismo consistiria em escolher os assuntos mais abjetos e mais triviais, as descrições mais repulsivas e mais lascivas. Seria, em resumo, dar a conhecer as pústulas da sociedade. Após ter livrado as mais horríveis chagas do cerato e das gazes que as cobrem, o naturalismo teria apenas um objetivo: fazer o público sondar sua terrível profundidade. (HUYSMANS in L'ACTUALITÉ, 1877, p. 249). ${ }^{14}$

No trecho da segunda parte do artigo em favor de Zola e de L'Assommoir, Huysmans argumenta que o naturalismo visava justamente expor tanto as camadas mais corrompidas ou indesejadas da sociedade quanto as mais distintas, mas não sem uma finalidade. O intuito do

\footnotetext{
${ }^{14}$ Mais avant que d'émettre des théories qui me sont toutes personnelles et qui n'engagent en rien, je me hâte de le dire, le journal qui les accueille, peut-être ne serait-il pas inutile de définir ces mots interprétés de façons si diverses : le réalisme ou le naturalisme. Selon les uns et, il faut bien l'avouer, selon l'opinion la plus accréditée, le réalisme consisterait à choisir les sujets les plus abjects et les plus trivials (sic), les descriptions les plus repoussantes et les plus lascives, ce serait, en un mot, la mise au grand jour des pustules de la société. Après avoir débarrassé les plus horribles plaies du cérat et de la charpie qui les couvrent, le naturaliste n'aurait qu'un but, en faire sonder au public l'épouvantable profondeur.
} 


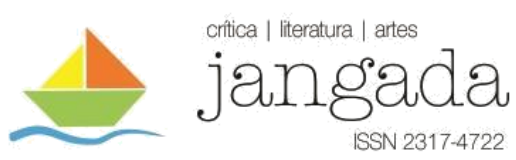

movimento literário era o de tratar certos assuntos sem querer atenuá-los ou abrandá-los, como o fazia Charles Dickens (1812-1870), citado por Huysmans. O naturalismo teria como foco aquilo que se entende como a verdade (do mundo material, social, e sua percepção), que não deveria ser escondida dos leitores. Desse modo, ele não consistiria em mostrar o horror pelo horror, mas em mostrar o que de fato ocorre na sociedade.

Nas páginas da revista L'Actualité, na edição de n. 31 de 18 de março de 1877, foi também publicado o capítulo II de La Fille Élisa, de Edmond de Goncourt. O polêmico romance, que narra a história de uma prostituta que termina por assassinar seu amante, seria publicado por Georges Charpentier naquele mesmo ano. Na revista, o capítulo foi acompanhado de uma nota que fazia referência à $L$ 'Assommoir, de Zola: "Esta terça-feira deve sair, pelo editor Charpentier, este livro predestinado às cóleras dos críticos que recentemente caíam sobre o livro de Zola. Devemos, graças à gentileza de um amigo, esse trecho característico que dará um aperitivo da forma e do conteúdo da obra." (L'ACTUALITÉ, 1877, p. 254). ${ }^{15}$ A motivação para a revista publicar o capítulo do romance antes que este saísse em volume também pode ser compreendida, dentro da lógica das relações úteis no campo literário, como uma maneira de Edmond de Goncourt divulgar no meio literário belga a obra a ser publicada por Charpentier em Paris.

A publicação dos quatro artigos de Huysmans e do capítulo de La Fille Élisa na revista dirigida por Lemonnier prova não apenas o engajamento deste último em relação ao naturalismo, ao qual sua obra será associada, mas também que um determinado grupo do campo literário belga tomava parte no combate em favor dessa estética literária. Isso seria sintomático da circulação de ideias que ocorria entre a França e a Bélgica. As estéticas literárias assim como as discussões e polêmicas atreladas a elas circulavam entre os dois países através da comunicação entre escritores e outros agentes implicados no campo literário, como editores, críticos e jornalistas. Os saberes e as informações passam de um espaço geográfico a outro por meio de importação de produtos culturais que são transmitidos por mediadores. A revista literária $L$ 'Actualité é um veículo através do qual Lemonnier assume a função de mediador do naturalismo francês na Bélgica. Estando o escritor ciente do impacto que exercia a obra de Émile Zola naquele momento no campo literário francês, não seria estranho que ele tomasse partido na polêmica, encomendando a série de artigos a Huysmans.

${ }^{15}$ C'est mardi que doit paraitre chez Charpentier ce livre prédestiné aux colères des critiques qui récemment tombaient le livre de Zola. Nous devons à l'obligeance d'un ami cet extrait caractéristique qui donnera un avantgoût de la forme et du fonds de l'ouvrage.

Jangada | ano 9, nr. 17, jan/jun, 2021 | ISSN 2317-4722 


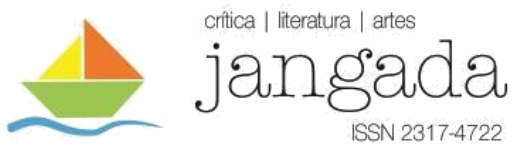

Há outra revista belga que pode ser considerada um veículo importante para o naturalismo: L'Artiste. ${ }^{16}$ A revista foi fundada em 1875, sendo primeiramente dirigida por Victor Reding. Porém, foi a partir de 1877, quando o poeta e pintor belga Théodore Hannon substitui Reding na direção, que a revista passou a assumir de modo mais evidente a defesa do naturalismo. Esse posicionamento é firmado no frontispício do periódico, através de divisa "Naturalisme-Modernité" (Naturalismo - Modernidade).

Huysmans, próximo de Hannon, colaborou diversas vezes com L'Artiste, publicando alguns poemas em prosa que antes haviam saído em Le Drageoir aux épices: "Rococo Japonais" e "Ritournelle" figuram na edição 22 de 3 de junho de 1877, "Camaïeu rouge", no número 25 em 24 de junho, e "Lâcheté" no número seguinte, no dia $1^{\circ}$ de julho. Além disso, Huysmans publicou críticas de arte nas páginas da revista, entre as quais podemos destacar aquela dedicada ao famoso quadro Le Rolla (1878) de Henri Gervex (1852-1929) ${ }^{17}$, na edição de 4 de maio de 1878, e "La Nana de Manet", em 13 de maio de $1877 .{ }^{18} \mathrm{O}$ artigo aborda o escândalo ocasionado pelo quadro Nana (1877), pintado por Édouard Manet (1832-1883), que havia sido recusado no Salão de Paris, o que fez com que o pintor o colocasse em uma vitrine no movimentado Boulevard des Capucines. Manet havia se baseado na personagem de Zola em sua primeira aparição, em L'Assommoir, e a cena pintada no quadro seria transposta posteriormente por Zola no romance Nana (1879-1880). ${ }^{19}$

O periódico ainda trouxe em suas páginas a primeira versão de $\operatorname{Sac}$ au dos de Huysmans, seriada nas edições 34, 36, 39, 40 e 42, entre os dias 26 de agosto e 7 de outubro de 1877. A novela viria a ser publicada posteriormente, em versão revista, na coletânea Les Soirées de Médan, concebida por Zola para reafirmar a existência do grupo de escritores naturalistas que se reuniam em sua propriedade em Médan, comprada graças ao sucesso comercial de L'Assommoir. Contava-se então a história segundo a qual os membros do grupo - que incluía além de Zola, Henri Céard (1851-1924), Paul Alexis, Léon Hennique (1850-1935), Guy de

${ }^{16}$ É preciso esclarecer que, apesar de ter o mesmo nome, essa revista literária não tem nenhuma relação com o periódico parisiense L'Artiste, órgão do romantismo em seus primeiros anos, tendo circulado de 1831 até 1904 (MELLO in MELLO; CATHARINA, 2007).

17 O quadro pode ser visto no site do Creative Commons: https://commons.wikimedia.org/wiki/File:Henri_Gervex_\%22Rolla\%22.jpg

18 O quadro pode ser visto no site do Creative Commons: https://commons.wikimedia.org/wiki/File:Edouard_Manet_037.jpg

${ }^{19}$ A pintura Nana de Manet demonstra que os apoios mútuos não ocorriam apenas entre escritores, mas também entre diferentes agentes das artes, como é o caso da pintura (Manet) se associando com a literatura (Zola). A união de forças com o campo literário foi particularmente buscada pelos pintores impressionistas na segunda metade do século XIX, tendo em vista que, contrariamente aos escritores, eles ainda não possuíam um campo que se pudesse dizer relativamente autônomo (CATHARINA, 2010). 


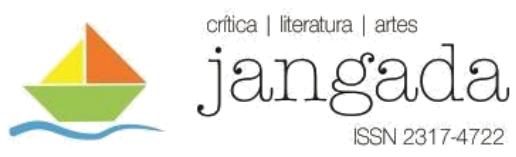

Maupassant (1850 - 1893) e Huysmans - teriam, em uma reunião, cada um contado uma história sobre a guerra Franco-Prussiana (1870-1871), dando origem à coletânea. A demarcação de um coletivo de escritores, como os naturalistas de Médan, teria como intenção não apenas servir de ponto de comunhão de concepções estéticas convergentes, mas também como um modo de defender-se de ataques externos, em especial aqueles advindos da crítica (BAGULEY, 1995, p. 21).

L'Artiste ainda republicou as duas primeiras partes do artigo de Huysmans sobre L'Assommoir (já publicadas nas páginas da L'Actualité), nas edições de 18 e 24 de março de 1877. Nas duas partes reproduzidas, o artigo é precedido de uma introdução: na primeira é elucidado o empréstimo feito à revista de Lemonnier (o que estabelece um novo laço entre os dois órgãos) e a intenção de desmistificar a imagem de Émile Zola, tido por seus detratores como um homem dissoluto, num jogo especular associando a vida do autor à obra. Já na segunda parte, o preâmbulo ressalta a brilhante defesa feita por Huysmans e avalia que as tendências naturalistas se encontravam "desenvolvidas com uma pena circunspecta", e que os leitores veriam que "o Naturalismo não consiste, em nenhum aspecto, em expor cinicamente, à luz do dia, [as] feridas, [as] deformidades e [os] vícios" (L'ARTISTE, 1877, p. 90). ${ }^{20} \mathrm{~A}$ republicação dos artigos pode ser compreendida não apenas como uma tomada de posição de L'Artiste, mas também como uma prova da existência de uma cadeia envolvendo escritores, editores e revistas literárias, agentes e veículos visando a difusão do naturalismo na Bélgica.

As revistas literárias demonstram como ocorrem as ações dos agentes em campo que buscam marcar seus posicionamentos. Nos casos mencionados, evidenciam a mediação que ocorria da literatura naturalista entre a França e a Bélgica. Podemos, desse modo, inferir que naturalistas franceses e belgas formariam uma tribo. Conforme compreende o linguista Dominique Maingueneau, as tribos de escritores se instauram a partir de reinvindicações estéticas comuns. Tais organizações são constitutivas do campo literário pois, por meio de grupos, cenáculos, escolas literárias, academias (GLINOER, 2020) e estratégias discursivas comuns, como publicações de obras revolucionárias (ou tidas como), críticas, manifestos, entre outros, condicionam o dinamismo presente no campo literário, podendo mesmo colaborar com a mudança de seu estado (MAINGUENEAU, 1993, p. 27-28). Tais ações são efetuadas pelos escritores que, além de produzirem e publicarem suas obras, ainda escreviam críticas,

\footnotetext{
${ }^{20}$ Les tendances naturalistes s'y trouvent développées de sérieuse plume, et l'on verra que le Naturalisme ne consiste en aucun point à étaler cyniquement au beau soleil, nos plaies, nos laideurs et nos vices.
} 


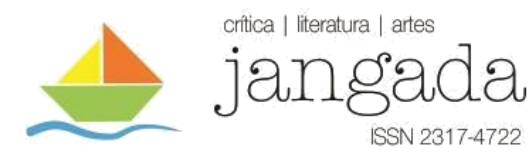

manifestos e refletiam sobre a estética que prezavam e defendiam. Os integrantes de uma tribo não precisam necessariamente estar no mesmo espaço físico ou geográfico, podendo haver processos de união ou de filiação nos quais seus os integrantes se comuniquem por cartas, se encontrem ocasionalmente ou apenas possuam similitude em seus modos de vida ou projetos convergentes (MAINGUENEAU, 1993, p. 28).

Além de Camille Lemonnier, Joris-Karl Huysmans e Edmond de Goncourt, citados anteriormente, na década de 1870 as revistas literárias belgas apresentam entre seus colaboradores outros escritores franceses vinculados ao naturalismo. Em L'Actualité, Zola publicou uma revue dramatique, nas edições de n. 28, de 25 de fevereiro, e n. 30, de 11 de março de 1877. Nas edições 37, 38 e 39, entre os dias 29 de abril e 13 de maio, saíram três artigos sobre La Fille Élisa e Edmond de Goncourt, escritos por Henry Céard. Este último publicou também em L'Artiste, além de poemas, seu romance Une belle journée de forma seriada entre os números 1 a 41, no decorrer do ano de 1878, antes que fosse lançado em volume em Paris por Charpentier, em 1881. Zola, por sua vez, propõe um perfil literário dos irmãos Goncourt na edição de número 24 da mesma revista, em 16 de junho de 1878, além de escrever uma coluna de periodicidade incerta intitulada "Causerie littéraire", que saiu até o número 21 daquele ano. Assim, retomando o conceito de tribo de Maingueneau, cogitamos a existência de uma tribo de escritores naturalistas entre a França e a Bélgica.

\section{NATURALISMO E TRANSFERÊNCIAS CULTURAIS EM PERSPECTIVA TRANSNACIONAL}

Pelo exposto acima, podemos pensar em termos de transferências culturais quando tratamos das relações e confluências entre escritores franceses e belgas no âmbito da literatura naturalista. Os caminhos para que esse processo ocorresse seriam, a princípio, fáceis de conceber: a proximidade geográfica entre a França e a Bélgica aliada ao fato de este último ser também um país, em parte, de língua francesa seriam facilitadores para o processo de transferência cultural. No entanto, existem ainda alguns fatores que é preciso considerar no que concerne à literatura naturalista na França e na Bélgica e em como esse fenômeno se caracteriza por uma certa simultaneidade na circulação de textos e de discussões estéticas.

O primeiro fator que devemos levar em consideração seria o modo como a literatura naturalista se desenvolveu na Bélgica. Embora o naturalismo tenha primeiramente se 


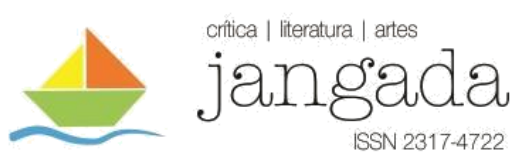

manifestado na França ${ }^{21}$, ao observarmos as publicações de escritores franceses nas revistas literárias belgas L'Actualité e L'Artiste, percebemos que as discussões em torno desse movimento literário ocorriam quase simultaneamente entre os dois países. Isso fica notório quando analisamos a maneira pela qual as revistas belgas conduziram a discussão envolvendo a polêmica de Zola e de seu romance L'Assommoir. Huysmans, escritor francês de ascendência holandesa que havia estabelecido relações com escritores e editores na Bélgica, seria um dos principais responsáveis por conduzir o debate sobre o naturalismo. $\mathrm{O}$ segundo fator seria justamente o naturalismo se configurar como um movimento literário internacional, desenvolvendo-se em vários outros países, cada um com características próprias que os emancipariam do que seria um "modelo francês" (BAGULEY, 1995, p. 7; CASANOVA, 1999, p. 146). Além disso, no que tange à abordagem em termos de transferência cultural, Michel Espagne considera que o objeto cultural que sofre importação de seu contexto de origem não é considerado em termos de originalidade. Como visto, ele avalia que "o contexto de origem como o de recepção são, antes mesmo da transferência, formas híbridas" (ESPAGNE, 2012, p. 24). Isso porque o produto cultural ou a forma artística e literária, em seu contexto dito “original”, seriam eles próprios resultados de outros processos de transferências, apropriações e ressignificações ocorridos anteriormente, o que por si só desmistifica conceitos como o de formas culturais "puras" e outras manifestações destas derivadas.

Considerando o modo como o naturalismo se desenvolveu na parcela do campo literário belga que abordamos aqui, seria interessante propor que as questões envolvendo as trocas correntes entre escritores da Bélgica e da França fossem examinadas em uma perspectiva transnacional. Segundo Blaise Wilfert-Portal, a história do continente europeu, em especial após a década de 1850, foi marcada por uma espécie de "primeira globalização", determinada por um crescimento exponencial de circulação de bens e pessoas, pela instauração de meios de transporte e comunicação como trens, navios e telégrafos, e pela organização de grandes instituições políticas e econômicas internacionais (WILFERT-PORTAL, 2013, p. 2). Assim, a circulação de bens e pessoas seria facilitada e, podemos deduzir, essa intensificação ocorreria com os produtos e formas culturais a partir desse período. Nessa perspectiva, as trocas entre Lemonnier e Huysmans, assim como a circulação de ambos (e a de outros escritores e agentes,

\footnotetext{
${ }^{21}$ Entendemos, com David Baguley, os romances Germinie Lacerteux (1865) de Edmond e Jules de Goncourt, Thérèse Raquin (1867) de Émile Zola e L'Éducation sentimentale (1869) de Gustave Flaubert como textos fundadores do naturalismo francês, fontes de temas, problemas e técnicas narrativas e romanescas a serem englobados pelo conjunto literário associado a essa estética (BAGULEY, 1995, p. 51-65).
}

Jangada| ano 9, nr. 17, jan/jun, 2021 | ISSN 2317-4722 


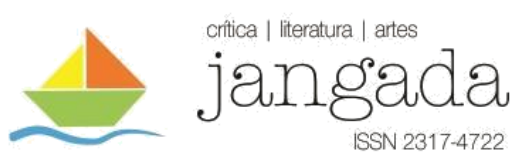

igualmente) entre os campos literários belga e francês, seriam representativas de um momento em que tais movimentos entre fronteiras nacionais encontravam-se em expansão.

Wilfert-Portal menciona ainda o período histórico que corresponde à Guerra dos Sete Anos (1756-1763), conflito que ocorreu sobretudo em torno da ideia de nação e de patriotismo, no qual monarquias nacionais travavam batalhas pelo controle de regiões de exploração colonial, que de modo paradoxal correspondeu igualmente a um período de circulação de obras literárias em contextos culturais diversos daquele que seria o de origem, fazendo emergir espécies de best-sellers pan-europeus, além de terem se intensificado os processos de tradução de obras romanescas (WILFERT-PORTAL, 2013, p. 5). Ao relativizar questões políticas relacionadas ao que seriam as "formas nacionais", Wilfert-Portal demonstra o modo como tais processos de transferências implicariam uma simultaneidade na apropriação de determinadas formas culturais. Espagne avalia que "as transferências culturais no interior do espaço europeu desenham em filigrana uma historiografia comum, [e] fazem emergir um tipo de homogeneidade ligada menos a um denominador comum do que à multiplicidade de deslocamentos" (ESPAGNE, 2004, p. 6). ${ }^{22}$ No que diz respeito à circulação de formas culturais entre espaços nacionais, isso acaba ocasionando uma certa simultaneidade em sua apropriação, tendo em vista os múltiplos caminhos pelos quais elas se deslocam. Podemos entender, desse modo, que o fato de o naturalismo ter sido apropriado por parte do campo literário belga em vias de autonomização foi consequência dos constantes deslocamentos entre agentes do campo literário, entre os quais escritores e editores, o que resultou em uma simultaneidade na apreensão não apenas da estética em si, mas também nas discussões que as envolviam, visando o reconhecimento pelos pares e a aceitação do público leitor.

Os diferentes tipos de deslocamentos que ocorreram entre países no contexto europeu também colaboraram para que escritores belgas publicassem livros e textos diversos em jornais e revistas na França, conseguindo até mesmo serem bem-sucedidos no campo literário francês. Temos como exemplo, mencionados neste artigo, Rodenbach, Verhaeren e o próprio Lemonnier. Este último teve relativa inserção no meio editorial francês, porém sem alcançar prestígio junto ao público leitor. Além dos escritores citados, um editor belga pode ser considerado um elo importante entre a França e a Bélgica, mais especificamente no âmbito da literatura naturalista. Henry Kistemaeckers tem a alcunha de editor dos naturalistas na Bélgica,

\footnotetext{
${ }^{22}$ Il est certain d'autre part que, si les transferts culturels à l'intérieur de l'espace européen dessinent en filigrane une historiographie commune, font émerger une sorte d'homogénéité liée moins à un dénominateur commun qu'à la multiplicité des passages.
}

Jangada | ano 9, nr. 17, jan/jun, 2021 | ISSN 2317-4722 


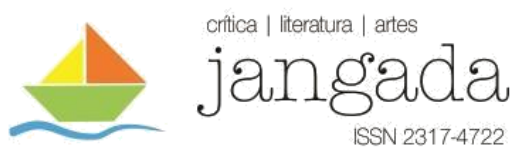

correspondendo em importância simbólica a Georges Charpentier na França. Ele publicou Un Mâle, de Lemonnier, além de diversas obras de escritores naturalistas franceses, como Mademoiselle Fifi (1882) de Guy de Maupassant, Le Collage (1883) de Paul Alexis, Autour d'un clocher (1884) de Henry Fèvre (1864-1937) e Louis Desprez (1861-1885), a novela À vau l'eau (1882) de Huysmans e Charlot s'amuse (1883), controverso romance de Paul Bonnetain (1858-1899) (COLIN in BECKER; DUFIEF, 2000, p. 44).

Logo, Kistemaeckers pode ser considerado igualmente um mediador cultural fundamental nesse processo de transferências culturais, não apenas por ter sido responsável pela publicação de obras dos escritores naturalistas franceses, mas também por efetuar a sua passagem clandestina, através da fronteira franco-belga, fazendo com que circulassem na França livros reputados escandalosos ou obscenos - o que foi feito apesar da fiscalização rigorosa por parte dos poderes públicos (VANWELKENHUYZEN, 2015, p. 17). A publicação, assim como a passagem de livros pela fronteira belga colocam Kistemaeckers na posição de difusor de obras naturalistas que, embora publicadas em um país estrangeiro, seriam parte integrante do campo literário francês.

\section{CONCLUSÃO}

A circulação de Lemonnier e Huysmans entre os campos literários belga e francês implica mediações culturais. Conforme vimos, ambos os escritores intermediaram contatos úteis com outros escritores e editores nos dois países, além de terem engendrado ações concretas visando causar certo efeito no campo literário, como a publicação por Huysmans dos artigos sobre L'Assommoir na revista dirigida por Lemonnier. Gustave Vanwelkenhuyzen, partindo de uma suposição de Léon Deffoux, levanta a hipótese de que Huysmans teria sido introduzido no meio literário belga através de Kistemaeckers, na ocasião de uma estada do escritor francês na Bélgica, em 1876. No grupo apresentado a Huysmans pelo editor, estaria Hannon que, por sua vez, o teria apresentado a Lemonnier (VANWELKENHUYZEN, 2015, p. 31). O estudo da correspondência entre os dois escritores não é conclusivo. No entanto, podemos pensar que Huysmans, por sua vez, talvez tenha introduzido Lemonnier nos círculos literários parisienses, ao intermediar contatos com editores e outros escritores.

O naturalismo se configura, assim, como um movimento literário internacional, com diversas manifestações em diferentes países, que não devem ser vistas como derivadas ou "imitações" do seu correspondente francês, que por seu lado não deve ser rotulado como Jangada | ano 9, nr. 17, jan/jun, 2021 | ISSN 2317-4722 


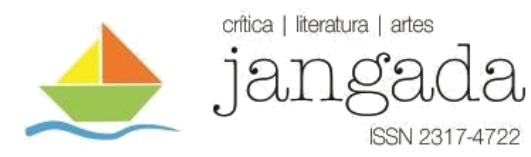

“original”. A circulação de escritores franceses e belgas entre os campos literários dos dois países é então representativa de deslocamentos que já ocorriam no contexto europeu e mesmo entre os dois países. A consequência desses movimentos através das fronteiras foi a confluência entre escritores belgas e franceses em relação ao naturalismo, com as ideias e discussões estéticas sendo apreendidas concomitantemente.

Ao contrário do que ocorreu com outros países, que assumiam temporalidades próprias segundo o grau de autonomização de seus campos literários (incluindo o Brasil, no qual a estética naturalista se desenvolveu), vimos que a apreensão e o desenvolvimento da estética naturalista na Bélgica aconteciam com certa concomitância em relação à França, o que é observado nas revistas literárias belgas e no modo como elas participaram das discussões envolvendo essa estética literária. Tendo isso em mente, é possível mesmo aventar que os escritores belgas a estavam pensando simultaneamente com os seus homólogos franceses. Podemos considerar essa hipótese quando examinamos o período no qual ocorreu a polêmica envolvendo L'Assommoir e a repercussão desta na série de quatro artigos de Huysmans e nas revistas literárias belgas: tudo se passa no ano de 1877, quando as revistas L'Actualité e L'Artiste assumem uma orientação naturalista, tomando parte na batalha literária em perspectiva transacional. As diversas possibilidades de composição da tribo viabilizaram a existência de um mesmo grupo pertencente a um mesmo movimento literário cujos membros vivem em dois espaços geográficos e políticos diferentes, como os naturalistas belgas e franceses. O conceito de tribo, sendo aplicado na observação das relações entre escritores naturalistas belgas e franceses, completa a noção de transferências culturais na medida em que ambos pressupõem não uma relação unilateral de "influência" ou dominação, mas intercâmbios multilaterais. As trocas no âmbito estético e das relações úteis entre Lemonnier e Huysmans dando-se através de cartas, intermediações com editores e outros escritores, e também em publicações em revistas literárias e jornais, constituem assim um exemplo da circulação do naturalismo entre a Bélgica e a França e, ao mesmo tempo, um novo momento na história das transferências culturais entre os dois países.

\section{REFERÊNCIAS BIBLIOGRÁFICAS}

BAGULEY, David. Le naturalisme et ses genres. Paris: Nathan, 1995. 
BIRON, Michel. L'autonomie nouvelle de la littérature. In: BERTRAND, Jean-Pierre; BIRON, Michel ; DENIS, Benoît ; GRUTMAN, Rainier (dir.). Histoire de la littérature belge francophone 1830-2000. Paris: Fayard, 2006, p. 139-149.

BOURDIEU, Pierre. As regras da arte: gênese e estrutura do campo literário. Trad.: Maria Lúcia Machado. São Paulo: Companhia das Letras, 1996.

BROGNIEZ, Laurence. Une "race" de peintres. In : BERTRAND, Jean-Pierre ; BIRON, Michel ; DENIS, Benoît ; GRUTMAN, Rainier (dir.). Histoire de la littérature belge francophone 1830-2000. Paris: Fayard, 2006, p. 117-126.

CASANOVA, Pascale. La République mondiale des lettres. Paris: Seuil, 1999.

CATHARINA, Pedro Paulo Garcia Ferreira. Huysmans critique de Zola. In : Excavatio. Edmonton: vol. XIV, n 1-2, p. 244-254, 2001.

Quadros literários "fin-de-siècle”: Um estudo de Às avessas, de Joris-Karl Huysmans. Rio de Janeiro: Sete Letras, 2005.

Livros, quadros e crítica na construção de um campo artístico autônomo. In:

GOUVÊA, Lucia Helena Martins; GOMES, Regina Souza (Org.). In: Anais do II Fórum Internacional de Análise do Discurso: Discurso, texto e enunciação. Rio de Janeiro: Faculdade de Letras - UFRJ, 2010, p. 42-51.

. Cenas da literatura moderna. Rio de Janeiro: 7Letras, 2007.

COLIN, René-Pierre. Henry Kistemaeckers, une histoire belge du naturalisme français. In: BECKER, Colette ; DUFIEF, Anne-Simone (dir.). Relectures des "petits " naturalistes. Nanterre: PUBLIDIX - Université de Paris X - Nanterre, 2000, p. 35-44.

COOPER-RICHET, Diana. Transferts culturels et passeurs de culture dans le monde du livre (France-Brésil, XIX ${ }^{\mathrm{e}}$ siècle). In : Patrimônio e Memória, v. 9, n. 1, p. 128-143, janeiro-junho 2013. Disponível em: http://pem.assis.unesp.br/index.php/pem/article/download/322/599 Acesso em: 09/05/2021.

DISEGNI, Silvia. Poème en prose et formes brèves au milieu du XIX ${ }^{\mathrm{e}}$ siècle. In : Études françaises, v. 44, p. 69-85, 2008.

DURAND, Pascal. La Librairie internationale A. Lacroix, Verboeckhoven et cie publie Les Misérables, de Victor Hugo. In: BERTRAND, Jean-Pierre ; BIRON, Michel ; DENIS, Benoît ; GRUTMAN, Rainier (Org.). Histoire de la littérature belge francophone 1830-2000. Paris : Fayard, 2006, p. 95-105.

ESPAGNE, Michel. Introduction. Revue germanique internationale, n. 21, p. 5-8, 2004. Disponível em: https://journals.openedition.org/rgi/988. Acesso em: 08/06/20.

. Transferências culturais e história do livro. Trad.: Valéria Guimarães. In: Livro: Revista do Núcleo de Estudos do Livro e da Edição. São Paulo: USP, n. 2, p. 21-34, agosto de 2012.

La notion de transfert culturel. Revue Sciences/Lettres, n.1, 2013. Disponível em: https://rsl.revues.org/219. Acesso em: 09/05/2021.

GLINOER, Anthony. Os grupos literários entre o social e o imaginário. In: Revista interFACES, v. 30, $\mathrm{n}^{\mathrm{o}}$ 2, p. 12-22, 2020. Disponível em: https://revistas.ufrj.br/index.php/interfaces/article/view/37904. Acesso em: 18/05/2021. GORCEIX, Paul (dir.). La Belgique fin de siècle. Bruxelles : Complexe, 1997. 


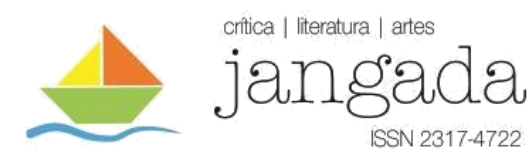

HUYSMANS, Joris-Karl. Le Drageoir aux épices. Paris: E. Dentu, 1874.

Lettres inédites à Camille Lemonnier. Genève: Librairie Droz; Paris: Librairie Minard, 1957.

. Romans et nouvelles. Paris: Gallimard, 2019. (Bibliothèque de la Pléiade).

JURT, Joseph. Traduction et transfert culturel. In: LOMBEZ, Christine; KULESA, Rotraud von; De la traduction et des transferts culturels (dir.). Paris: L'Harmattan, 2007, p. 93-111.

LEMONNIER, Camille. Nos Flamands. Bruxelles: Rozem, 1869.

Croquis d'automne. Bruxelles: C. Muquardt, 1870.

. Contes flamands et wallons. Paris : Librairie de la société des gens de lettres, 1873.

Un Coin de village. Paris: Alphonse Lemerre, 1879.

Les Charniers. Paris: Alphonse Lemerre, 1881.

. Un Mâle. Bruxelles-Paris: Henry Kirstemaeckers; Marpon \& Flamarion, 1882a.

Le Mort. Bruxelles: Henry Kirstemaeckers, 1882b.

LEMONNIER, Camille; BAHIER, Anatole; DU BOIS, Jean. Un Mâle; pièce en quatre actes. Paris: Tresse \& Stock, 1891.

LEMONNIER, Camille; MARTINETTI, Paul. Le Mort; mimodrame en trois actes. Bruxelles:

Typographie-Lithographie Populaire, 1894.

LEMONNIER, Camille. L'Homme en amour. Paris: Paul Ollendorf Éditeur, 1897. . Adam et Ève. Paris: Paul Ollendorf Éditeur, 1899.

LEMONNIER, Camille ; MARTINETTI, Paul; DU BOIS, Léon. Le Mort; mimodrame en trois actes. Bruxelles: Breiktor \& Haetel, 1900. (Partitura musical).

LEMONNIER, Camille. Edénie; tragédie lyrique en quatre actes. Bruxelles: Oscar Lamberty, 1910.

La Vie belge. In: GORCEIX, Paul (dir.). La Belgique fin de siècle. Bruxelles: Complexe, 1997, p. 63-214.

LOUVEL, Liliane. Modalités du pictural. In: LOUVEL, Liliane. Texte/Images: images à lire, textes à voir. Rennes: Presses Universitaires de Rennes, 2002, p. 16-44.

MAINGUENEAU, Dominique. Le contexte de l'œuvre littéraire : énonciation, écrivain, société. Paris, Dunod, 1993.

MELLO, Celina Maria Moreira. O prosaico, o literário e o político em L'Artiste (1831-1839): renovação das cenas genéricas do romantismo francês. In: MELLO, Celina Maria Moreira;

MOLLIER, Jean-Yves. O dinheiro e as letras: história do capitalismo editorial. Tradução: Katia Aily Franco de Camargo. São Paulo: Editora da Universidade de São Paulo, 2004.

O dinheiro e as letras, um comércio delicado. In: Leitura, Ano 5, n. 5, 2011. Disponível em: http://www.casaruibarbosa.gov.br/escritos/numero05/artigo02.php Acesso em: 13/05/2021.

PAGÈS, Alain. La bataille littéraire. Essai sur la réception du naturalisme à l'époque de Germinal. Paris: Librairie Séguier, 1989.

PEDROSA, Rubens Vinícius Marinho; CATHARINA, Pedro Paulo Garcia Ferreira. Quadros de quermesse em Un mâle, de Camille Lemonnier: um topos naturalista. In: Scripta Uniandrade, v. $17, \quad$ n. 1, p. 208-233, 2019. Disponível em: 


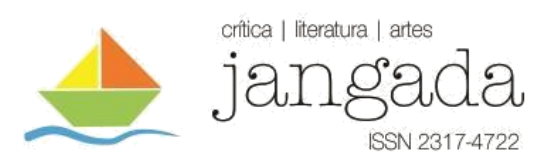

https://revista.uniandrade.br/index.php/ScriptaUniandrade/article/view/1238 Acesso em: 02/06/2020.

SILEM, Ahmed. Passeur culturel et économie de marché. In: COOPER-RICHET, Diana ; MOLLIER, Jean-Yves ; SILEM, Ahmed. Passeurs culturels dans le monde des médias et de l'édition en Europe (XIX ${ }^{e}-X X^{e}$ siècles). Lyon: Presses de 1'ENSSIB, 2005, p. 301-317.

VANWELKENHUYZEN, Gustave. J.-K. Huysmans et la Belgique. Bruxelles: Samsa Édition, 2015.

WILFERT- PORTAL, Blaise. L'histoire culturelle de l'Europe d'un point de vue transnational. In : Revue Sciences/Lettres n. 1, 2013. Disponível em: http://journals.openedition.org/rsl/279 Acesso em: 09/05/2021.

\section{Jornais e revistas literárias consultados:}

L'ACTUALITÉ, Bruxelles: v. 1, 1876-1877, n. 1 à 52. Disponível em: http://digistore.bib.ulb.ac.be/2013/ELB-ULB-a098-1876-1877-000.pdf. Acesso em: 12/08/2020.

L'ARTISTE, Bruxelles: v. 2, 1877, n. 1 à 52. Disponível em: http://digitheque.ulb.ac.be/fr/digitheque-revues-litteraires-belges/periodiquesnumerises/index.html\#c13445. Acesso em: 10/07/2020.

L'ARTISTE, Bruxelles: v. 3, 1877- 1878, n. 1 à 43 . Disponível em: http://digitheque.ulb.ac.be/fr/digitheque-revues-litteraires-belges/periodiquesnumerises/index.html\#c13445. Acesso em: 10/07/2020.

LE FIGARO - Supplément littéraire du dimanche, 2 avril 1876. Disponível em: ark:/12148/bpt6k281848g Acesso em: 01/05/2021.

LE FIGARO - Supplément littéraire du dimanche, 2 $2^{\mathrm{e}}$ année, n. 46, 05 novembre 1876. Disponível em: ark:/12148/bpt6k281848g Acesso em: 01/05/2021.

LE FIGARO - Supplément littéraire du dimanche, 4e année, n. 36, 08 septembre 1878. Disponível em: ark:/12148/bpt6k2738024 Acesso em: 01/05/2021.

LE FIGARO - Supplément littéraire du dimanche, 4e année, n. 38, 22 septembre 1878. Disponível em: ark:/12148/bpt6k2738024 Acesso em: 01/05/2021. 